\title{
CAPTURING ZEITGEIST ON CYBER LITERATURE: A CASE OF @NKCTHI ON INSTAGRAM
}

\author{
Emma Natasha Octoveria ${ }^{1}$, Natrila Femigasari², Nadia Athali $^{3}$ \\ English Department, Universitas Gajah Mada \\ natshoffice@gmail.com¹, natrila.f@mail.ugm.ac.id ${ }^{2}$, nadiaathali@mail.ugm.ac.id³
}

\begin{abstract}
The advancement of technology, particularly the internet, has given cyber literature a prominent public recognition for its wide availability online and it has also acquired a place among the world of literature. Using the concept of zeitgeist proposed by Krause and relating it to the cyber literature on Instagram with the cultural phenomenon that is happening in Indonesia in 2018-2019, this research aims to address these questions: (1) why Instagram becomes the zeitgeist of cyber literature and (2) how Nanti Kita Cerita tentang Hari Ini (NKCTHI) reflects the zeitgeist of cyber literature on Instagram. Other than that, by considering Yongqing, Pignanolli, and Hayles' works on digital media and cyber literature, this research found that the proliferation of cyber literature does not diminish printed literature. Instead, by investigating the phenomenon of the rising popularity of NKCTHI in Instagram, this research came to what Yongqing has suggested that cyber literature complements printed literature.
\end{abstract}

Keywords: cyber literature, instagram, zeitgeist, NKCTHI

\begin{abstract}
Abstrak
Seiring dengan perkembangan teknologi internet, sastra siber yang dapat dengan mudah diakses khalayak ramai secara daring mulai mendapat tempat di dunia kesusastraan. Menggunakan konsep zeitgeist yang dibahas oleh Krause, penelitian ini bertujuan untuk memahami fenomena sastra siber di Instagram dengan mengaitkannya dengan fenomena kultural yang terjadi di Instagram di Indonesia pada periode tahun 2018-2019, untuk menjawab pertanyaan: (1) mengapa Instagram dapat menjadi zeitgeist dari sastra siber dan (2) bagaimana Nanti Kita Cerita tentang Hari Ini (NKCTHI) mewakili zeitgeist dari sastra siber yang ada di Instagram. Selain itu, merujuk pada penelitian yang sudah dilakukan oleh Yongqing, Pignanolli, dan Hayles, hasil penelitian ini menemukan bahwa adanya sastra siber tidak serta merta menghapus keberadaan sastra tradisional dalam bentuk cetak. Alih -alih, seperti yang Yongqing telah paparkan, dengan menyelidiki fenomena populernya NKCTHI di Instagram, penelitian ini berkesimpulan bahwa sastra siber melengkapi sastra tradisional yang telah ada.
\end{abstract}

Kata Kunci: sastra siber, instagram, zeitgeist, NKCTHI

\section{Introduction}

The world is continuously evolving and so is literature. In the modern era, literature changes alongside the growing existence of the Internet. In the 1990s, the emergence of the Internet following the invention of the World Wide Web (WWW) was imminent. As a consequence, the Internet has been an inherent part of our lives. People can no longer seem to function properly without the Internet, for any 
kind of information can now be obtained through the internet, that even some information is exclusively available online. Accessing and retrieving information is made as easy as a fingertip away through the internet accessible from mobile phones (Katherine Hayles, 2012). This dependency on the Internet, therefore, explains the growing number of cyber literature.

Cyber literature has been gaining continuously prominent attention along with the advancement of the Internet, specifically in the past two years, from the beginning of 2018 until the last quarter of 2019 and counting. The internet has become a great aid for cyber literature in terms of its worldwide dissemination that is far beyond what print can reach (Katherine Hayles, 2012). Specifying into what platforms can cyber literature be published, there are several platforms that can accommodate the posting, ranging from blogging platforms, e.g. Wattpad, Blogger, and Wordpress, to social media platforms, e.g. Facebook, Instagram, and LINE. Here are the statistics record of some blogging platforms: Wattpad currently has 80 millions readers (Anderson, 2019) by 2019 and Wordpress engages with 175 Million page views per month (Barron, 2019). Although people commonly treat blogging platforms as the main source where they can find cyber literature, their popularity among internet users are beaten by the increasing use of social media platforms worldwide, one of them is Instagram.

Established in 2010 by Mike Krieger and Kevin Systrom and acquired by Facebook in
2012, Instagram is a mobile application one can use to share pictures and videos (Stout, 2019). Instagram successfully acquires a prominence of being the second most used social media platform worldwide with over 1 billion monthly active users (Stout, 2019), with $34 \%$ of it belonging in the age group of young adults, aged from 18-34 years (Clement, 2019). Users of Instagram are able to share content called Instagram posts to their followers-other users who follow them-or with their groups of friends. , The application also allows its users to see, comment, and like the posts within. With a mobile device of any operating device, anyone over the age of 13 may sign up on the application using an email account, then the application will provide modifiable usernames for them (Instagram, n.d.). Instagram has successfully turned the table by accommodating the publishing of cyber literature that can reach a much wider scope of the audience compared to blog due to its easy accessibility as well as plenty of features it has to offer, synthesizing visual matters in the form of video and images with written matters through captions.

On the emergence of cyber literature, Instagram nurtures an endless potential for people to create contents that are not limited to photos, but also writings that can be displayed in an image format. Not only does this make it easier for people to access cyber literature, particularly forms of literature that are short, e.g. short stories, poems, quotes, or excerpts of verses, but this also gives a more visuallyappealing nuance that attracts more people to notice it, hence the wide exposure. An Indonesian-based Instagram account @nkcthi, a short 
for Nanti Kita Cerita Tentang Hari Ini (in English: We Will Tell the Story of Today), is used to exemplify the emergence of cyber literature on Instagram due to its ongoing popularity that began in February 2018 when it was first established. @nkcthi serves prose as its main content, conveying a collective expression of feelings and state of mind, such as life advice, reassurance, and simply the hard truth about life delivered through engaging short prose. Therefore, this research attempts to use @nkcthi Instagram page as a base in understanding cyber literature, because it manages to capture the current trend of cyber literature on Instagram. Having an awareness that people go to Instagram mostly expecting to see images or videos that are visually attractive or simply easy on the eye, @nkcthi combines a collection of prose with visual aspects through hand-drawn digital illustrations as its contents.

Through observing the emergence of Instagram as one of the most popular social media platforms in 2018 to 2019 and taking an Instagram account, @nkcthi, as an epitome of the rising trend of the same period of time, two questions arise then: why does Instagram serve as an effective modes of being to disseminate certain zeitgeist? What kind of zeitgeist does @nkcthi aim to express through Instagram? Finally, the last question would lead us into the question of how to treat cyber literature and the effect it has shaped how people think in the modern age.

\section{Zeitgeist}

Before proceeding further into the discus- sion, it would be more comprehensive to use the concept of zeitgeist to understand the phenomenon of @nkcthi and cyber literature. In the literal term, zeitgeist means 'a spirit of the times' (Webster, n.d.). As Krause has suggested, using the concept of zeitgeist to understand the cultural phenomenon is very useful because zeitgeist serves as a tool to dissect a pattern that is specific to a particular historical timeperiod and also links to different realms of social lives and/or groups. Zeitgeist has some important characteristics; duration, scope, course, as well as media and carriers (Krause, 2019). Firstly, zeitgeist is very heavily related to the extension of time, in which it asks when and for how long the emergence of a cultural change pattern can be detected. Secondly, a zeitgeist is exclusive to certain social groups. A zeitgeist will affect to some social groups more than others and even extends to transcend beyond geographical areas. Thirdly, the course aspect asks how long a zeitgeist evolves over time. A zeitgeist can emerge or recede suddenly. It also can become part of common sense for centuries. Last, a zeitgeist has media and carriers. People, in general, have been known for being the carriers of a zeitgeist. However, with the advent of the Internet, now, mass media and technologies are becoming the carriers of zeitgeist. In some cases, the zeitgeist that media and technologies carry lasts longer than the actual cultural phenomenon itself. Borrowing the last characteristic observed by Krause about zeitgeist, this research is compelled to address why Instagram is the zeitgeist of cyber literature and why it is effective to be the carrier of a zeitgeist. 


\section{Cyber Literature}

Many terms have been used to refer to cyber literature. As stated by Rahman (2017), some cyber literature researchers have referred it as literary machine (Nelson, 1993), cybertext (Eskelinen, 2012), digital literary (Hoover, 2014), digital media (Ryan, 2013), digital literature (Sanz, 2007), electronic literature (Hayles, 2001), and also, online literature (Yongqing, 2011). In this research, the term cyber literature is used because it apparently alludes to two things: the conventional literary tradition and the literary on the internet (Rahman, 2017).

Cyber literature, as Yongqing has argued, comes from the integral coalescence of the Internet and literature. This phenomenon is under what is called the mediazation of modern culture, where modern culture has been affected by new technologies and media (Yongqing, 2011). Brought up by this relatively new form of literature are its evident modernity and distinctive features, which are the results of the Internet's involvements, that distinguish it from traditional literature (Yongqing, 2011). Among the distinctive features of cyber literature is the implementation of multimedia, which researchers deem as the most comprehensible contrast to that of traditional literature (Yongqing, 2011).

Nevertheless, the definition of cyber literature is clearly drawn first as to avoid misunderstanding. As Yongqing has suggested, there are some misconceptions among scholars when discussing cyber literature. First and foremost, cyber literature is not literature about the Internet, nor is it literature on the Internet. As mentioned before, because cyber literature yields from the integration of literature in printed forms and the Internet, it should be noted that when discussing cyber literature, the relationship and the Internet as dialectical and interactive should be taken into consideration (Yongqing, 2011). Therefore, cyber literature should be seen as a selfsufficient organic unity that includes: writing, publishing, disseminating, and interacting with readers.

The vast majority of cyber literature texts are mainly short (Conde, 2012). There are three main branches that could be drawn from these short texts. Those are: micro-fiction, micro-poetry, and micro-drama. The word 'micro' in the texts refers to the length of the work that is usually very short. On the other hand, there are several aspects that make cyber literature successful in drawing huge attention. Those are: (1) worldwide access, (2) immediate update about the work, (3) immediate re-edition of contents, (4) its briefness, (5) frequent lack of a quality filter, (6) writers become publishers, (7) sites or blogs become a kind of magazine, (8) a Creative Common license is often added, (9) writers and readers are able to interacts, and (10) it is virtually free for both authors and readers (Conde, 2012).

\section{Instagram and Cyber Literature}

Online writing, as Yongqing notes, is less utilitarian and more artistic and enjoys more freedom. In the modern age, everyone could write and express their feelings in an unlimited way that no one has ever imagined before. On the other hand, this ease of access that is en- 
joyed by people mystifies the concept of an author. Online writing eliminates traditional ideas about what being an author means. It is with the replacement of media and technologies that contribute to the ever-changing meaning of the author, as the concept of the author itself is a historical product (Yongqing, 2011). In the traditional sense, being an author means that one who writes and publishes his works in printed forms. While in the modern sense, one may call himself as an author even though his work is not in printed forms, but circulated through the digital media. This phenomenon is obviously felt by well-known writers. Eka Kurniawan (2019), one of the famous Indonesian authors, wrote in one of his essays entitled Ketika Semua Orang Bisa Bicara, Apa Tugas Penulis? (Everybody Can Talk, So What Does An Author Do?) pondering what then the meaning of being an author in a traditional sense where in this modern age one could write and express about anything.

While it is true that the advent of digital media blurs the line between the meaning of the author in the traditional sense and modern sense, digital media, particularly Instagram, serves as an important platform for readers-writers that could enhance their experience in reading literature. Because the literary-historical change in the digital age rarely involves the complete replacement of older features, in fact, literary-historical change in cyber literature reshuffles of existing features in the light of new function (Pignagnoli, 2019). Now, writers could know the response of their readers even when they are still in the process of writing the work. Writers could easily get feedback and comments from readers through Direct Message (DM) feature on Instagram, for instance. The dialectical interactions from writers and readers then creating a certain value that is different from other writers-readers responses. In this light, thus, the kind of value, particularly, zeitgeist, that the writers-readers make can be detected through the use of Instagram as modes of being for cyber literature.

\section{Instagram as the Zeitgeist of Cyber Litera- ture}

The existence of internet cookies that are used to "track down individual's activity on a particular website across the internet by storing website preference" (Mooney, 2013) through history of all websites visited as well as all search terms the user has entered within a certain platform (Mooney, 2013) enables people to be exposed to the information in accordance with their recent search history without them having to look for it. Following this, the emergence of Instagram as one of the most powerful social media of this past couple of years is further aided by its algorithm that uses cookies; it is tailored not only in chronological order but also in order of preference, meaning that once a user unconsciously likes a couple of posts of the same type of content, the content that will be displayed in the explore tab will show verisimilitudes of posts. For instance, if a user taps like on a couple of posts containing excerpts of Bible verses, Instagram's algorithm will display excerpts of Bible verses posts by many other accounts in the explore tab of the 
user's account without the user having to follow the accounts whose contents are being displayed. This algorithm becomes a great aid for content creators to have a wide exposure because Instagram users can find an account unintentionally and if they like the contents posted by that account, they can choose to follow it, unlike blog posts that should first be put into a search query to be found.

Instagram emphasizes this feature by providing a dedicated tab called 'explore' which displays various contents from all around Instagram, predominantly from accounts Instagram users do not intentionally follow in the first place. Without users having to enter any search query, Instagram will tailor their preference from the history of their previous search queries and type of posts they tap like on to display similar posts from their preference. Not only that, with this explore feature taking on the privilege of using cookies feature, they are also given suggestions of accounts exhibiting the preferred contents they can choose to follow. This overall pattern of information as something that is no longer obtained, but is served on the internet constitutes an ongoing pattern among the users of Instagram that can be deemed to be the zeitgeist of Instagram users.

Before Instagram, people used to go directly to blogging platforms, such as Wattpad, Blogspot, or Wordpress to look for poems, short stories, prose, and other means of literary work available online. However, since the thorough development of Instagram with some features that can substitute blogging platforms, such as long caption and multi-post, where a user can post up to 10 photos over one post, people tend to go to Instagram for it has already covered plenty of features that much other social media platforms. This gradually shifts the paradigm of cyber literature, for people can now easily find relatively short models of literary works, predominantly poems, prose, and short stories on Instagram.

Instagram's easy accessibility may pose a threat for blogging platforms, because, in terms of accessibility, Instagram offers a myriad of choices without people having to come up with a search query on a particular author or title; they can simply use the hashtag (\#) feature where they can simply enter a keyword, such as \#poems or \#quotes, and Instagram will display the search results that best match the categories. However, this change does not merely endanger the imminence of cyber literature, for it only switches the platform preference; from blogging platforms to social media platforms. Although the preference of the forms of cyber literature also shifts from slightly long literary forms that are typically posted on blogging platforms to shorter ones, such as prose, poems, and quotations, it cannot simply be treated as a threat to the popularity of cyber literature. This, instead, keeps people's awareness towards literature, particularly on the internet, without them intentionally expecting so.

\section{Nanti Kita Cerita tentang Hari Ini as a Form of Cyber Literature}

Nanti Kita Cerita tentang Hari Ini (NKCTHI) is a literary work written by Indonesian author, Marchella FP. It takes form in an Instagram 
page in which its contents are published (@nkcthi). This combination of the prose as its content and the illustration design is conveyed well that over 1.4 millions of Instagram users follow the account as per November 2019, as well as the engagement of the account by users that are not following the account, which is presumed to be bigger than the number of followers in total. None of the two aspects is put aside or sacrificed in order to have one feature, neither the prose as its content nor the illustration, stands out from one another, for the two go simultaneously, making the overall content emotionally and visually appealing at the same time.

@nkcthi started out on Instagram with its very first post being uploaded on February 25,2018 . In less than a year later, in October 2018, the printed version of the literary work was published, proving that @nkcthi had captured a wide range of readers in the country. It is safe to say that the likableness of @nktchi 's contents is not in any way to be doubted.

There are several reasons as to why $@$ nkcthi has succeeded in becoming one of the most popular cyber-literary works in Indonesia, some of them being its combining mere texts with eye-catching digital drawings or illustrations, the fact that many of the readers find the work to be relatable, and the considerably short length of the work which makes it easier to read (micro-fiction). As mentioned before, one feature of cyber literature that most distinguishes it from traditional literature is its active usage of visually engaging illustrations or multimedia. In the case of @nktchi, the contents combine digital drawings with texts. Possessing an aesthetically pleasing visual presentation helps @nkcthi in becoming a literary work with more interesting tone, which is proven to be much more preferred by the readers. On one Instagram post dated April 7th, @nkcthi posted one of the reader's responses saying "at first, I was disappointed with the book. But, when I am in a bad mood, reading this [NKCTHI] book brings me positivity. Thanks!" In addition to this, the relatability of the content seems to be a major support in @nkcthi ‘s success. The other responses from readers said that they could feel the story more when they are on their lowest day. This is due to the contents' representing many different narratives by covering different topics or themes. For example, one post contains advice on love life, as seen in figure 1 below:

Figure 1

A Post on Love Life

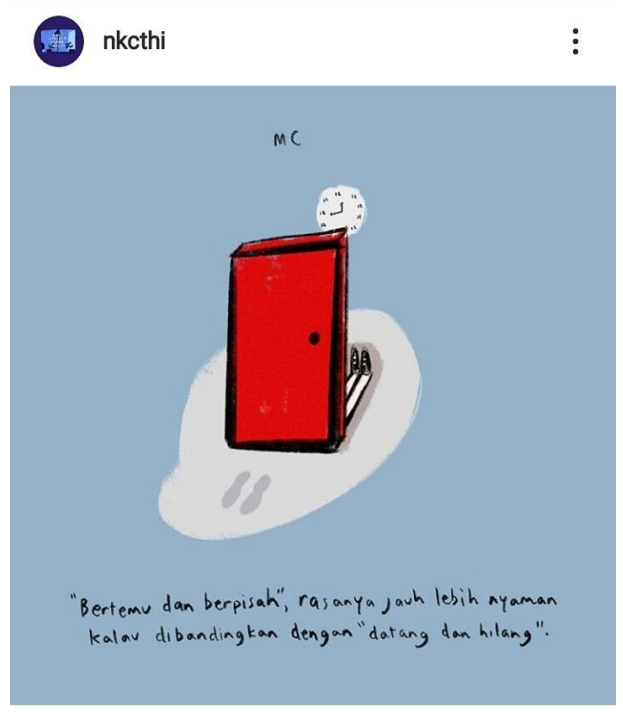

Notes: a post on love life, which translates to "To meet and parting away' feels better than 'to come and then disappear'" in English (2018).

Meanwhile, another does similarly on self-care, as seen in figure 2 below: 
Figure 2

A Post on Self-care

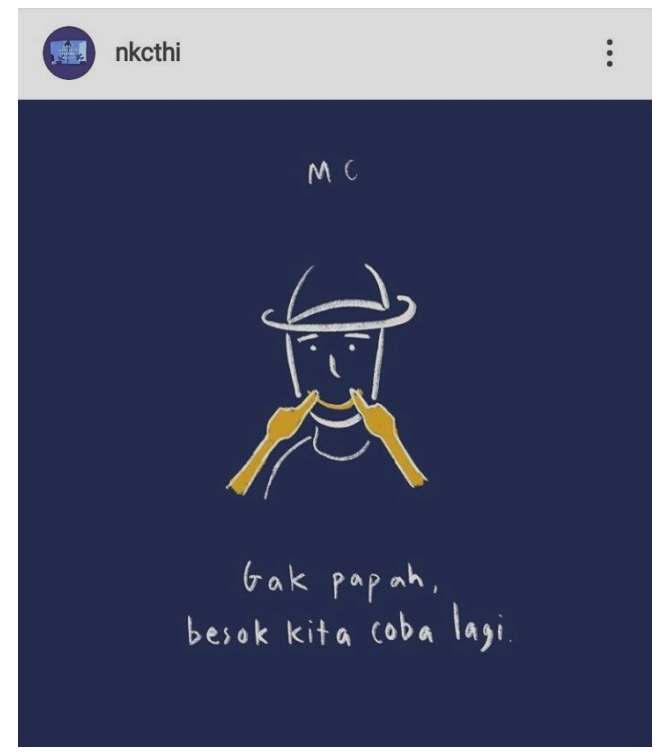

Notes: a post on self-care, which translates to "It's alright, tomorrow we will try again" (2018).

This wider range of topics or themes that are possessed by @nkcthi is achieved without making the literary work too long, which would bore the readers. It simply helps the account in reaching a wider audience on Instagram, for the relatability of the contents helps raise the engagement rate of the account. This smart move on deciding the length of the contents is related to the effectiveness of @nkcthi 's contents in reaching the readers. As mentioned before, though combining both texts and illustrations, @nkcthi keeps its contents short and precise. Each post contains only one to three sentences on average in the form of an image with 1:1 resolution, with drawings or illustrations added in the background. This simplistic yet effective combination seems to be the most selling point of @nkcthi and other similar works for their readers.
In the case of @nkcthi, the integration of digital technology, Instagram, and literature indirectly implies what kind of zeitgeist that is being carried from this integration. Furthermore, the zeitgeist affects certain social groups more than others, in this case, the young people. This finding in its nature is not unique. Hayles found that young people are doing more screen reading of digital materials than ever before, making them susceptible to the exposure of various forms of cyber literature (Katherine Hayles, 2012). Instagram as a platform itself clearly has made accessibility reachable for @nkcthi. As previously discussed in this research, Instagram provides features that can be taken advantage of by creators such as Marchella FP to establish a growing audience. Hashtags and explore page features are especially useful for readers to find content that are suited to their own narratives. In the case of @nktchi, the two features bring readers from other accounts or posts similar to it, even the ones who do not follow @nkcthi can still discover its contents through the Instagram cookies algorithm. This helps in keeping the engagement between writers and the readers of their works growing. As proven by @nkcthi, the collaboration of a literature work and digital platform, in this case, Instagram, has shaped the zeitgeist of Indonesian young adults, with accessibility and relatability being its main points.

\section{Not Opposites, but Complements}

The world of literature is evolving and change is happening in the publishing ground of the literary world; from its traditional or conventional nature to virtual media, and this 
has grown not only partially, but gradually reaching an overall nature of the literary world itself (Rinaldi, 2019). This is widely perceived as the death of traditional literature that in this era everything seemingly takes place in cyberspace. However, this pessimistic way of perceiving cyber literature as a threat is not something worth cultivating. As Yonqing remarked: "Traditional literature and online literature are not opposites but complements; together, they make up the literary spirit of our era" (Yongqing, 2011). The integration of cyber literature and traditional literature reshapes the way a literary work gets published and that does not merely mean that the imminence of cyber literature diminishes traditional literature.

Using @nkcthi to exemplify this integration of cyber literature and traditional literature, there needs to be an understanding that @nkcthi eventually got published in a printed form on October 2018, less than a year after its first Instagram appearance on February 2018, and 5000 copies were sold in less than 24 hours after its first day of selling (Desfourina, 2018). How cyber literature transforms into traditional literature proves that there is a new pattern in the publishing of literary works that never happened prior to the emergence of the internet. If traditional literature publishing used to focus on a literary work as a single entity, in which popularity is seen from the recognition of the readers after it is published, the publishing of cyber literature adopts 'test the water' method. Starting from the internet, specifically in the case of @nkcthi is through Instagram, the writer be- gan by posting prose in the form of Instagram posts to see whether people on Instagram favored the kind of content @nkcthi had to offer. In the case of @nkcthi, people of Instagram responded positively, proven by the massive growth of followers that reached hundreds of thousands of followers within months, and this attracted POP Gramedia as a publishing house to create the printed version of the content; of what had been around the internet, and in the end, it became a big hit that it was on the twelfth print only in three months after it was first published (IDN Times \& Pertiwi, 2019). This method of 'testing the water' along with its positive impact in boosting a work's popularity has inspired Marchella FP to take advantage of it for the release of her other works. @ktbb.ktbb (Kamu Terlalu Banyak Bercanda or You Joke Around too Much in English) and $@$ @pbm.ppbm (Pura Pura Bukan Manusia or Pretending to be Non-Human in English) are two of some titles that are mentioned in @nkcthi ‘s bio.

As previously discussed in the paper, this action of promoting the newer works are done by testing the water; promoting them through an already-popular account(s), in this case, @nkcthi as the successor. This helps the new titles, whose contents are fairly similar to those of @nkcthi ‘s, gain attention and build an audience, even a community of their own as their accounts grow. In the case of @ktbb.ktbb, which the author claims to be the night to @nkcthi 's morning, having tested the water through @nkcthi helped the account to gain over 164.000 followers as per November 2019 in only a year after its first post on November 
2018. Not long after, in April of 2019, the book of Kamu Terlalu Banyak Bercanda was published, becoming another success of Marchella FP after @nkcthi. More impressively, @ppbm.ppbm, the unreleased work of Marchella FP whose first and only post was uploaded only on June 7, 2019, has gained over 13.600 followers by November of the same year. It is important to note that @ppbm.ppbm has not even published its contents and the enthusiasm, which was gathered by 'testing the water', reflects nothing of the account's age ( 5 months old only). From these examples, one can conclude that testing a work's popularity and its capability of reaching a certain target market is essential in the process of creating cyber-literary works.

Having examined how @nkcthi started as cyber literature to its publishing as a book, or how traditional literature takes form, supports the argument that cyber literature is not a threat for traditional literature, for it instead serves a complementary to one another. Social media platforms as aids for cyber literature to flourish encourage new writers to be confident to try to start writing. Writers can now easily test the water to see how people respond to their literary work by posting it on social media platforms, such as through Instagram. Aside from seeing how people react to their work, writers can also receive insights such as feedback and suggestions that can help them constantly improve their work for the better; social media posts of cyber literature provides two-way communication and immediate interaction between writer and reader (Yongqing, 2011). Moreover, this new pattern of testing the water through social media, departing cyber literature to finally be in its traditional form as a book, can lessen the doubt writers may have if they are anxious about whether people will favor or purchase their literary work. There should be a realization that cyber does not necessarily post a threat to traditional literature; just because it exhibits a new pattern the literary world has never seen before, because the internet is a new breakthrough that changes the overall paradigm of the world, it does not mean that cyber literature ruins the schema of literary publishing. Once people become aware of this, a new hope for the literary world will even emerge through the surfacing of more new writers that will preserve the world of literature in the long run.

The discussion above takes on Instagram as one of the most used social media platforms from 2018 to 2019 with @nkcthi as an account serving as a cyber literature portrayal. A new pattern of publishing in the world of literature can be seen in the case of @nkcthi which departs from cyber literature and ends up being published as a book, just as how traditional literature takes form. The limitation of this research accommodates the two; Instagram and @nkcthi, but the same pattern as what @nkcthi went through is also happening throughout the internet on other social media platforms, such as the upcoming publishing of @budesumiyati's collection of prose that began from her tweets on Twitter and the incoming publishing of Jespica and Nazale Kusuma's zine of poems which were initially posted on LINE account of Phos- 
phenous, which generates rich possibilities of future research regarding cyber literature that gets published.

\section{Conclusion}

As has been discussed above, it is clear that Instagram can be said as the zeitgeist for cyber literature in Indonesia. Taking the case from @nkcthi, Instagram has been one of the main tools in shaping the zeitgeist of Indonesian young adults' literacy, with accessibility and relatability being its main points. Further, Instagram also helps modern writers like Marchella FP. One of the patterns of the zeitgeist that is found is that more and more writers establish their credibility first on Instagram to see how the readers would respond to their works and then get their works published after seeing the responses. Certainly, such a method is unable to be imagined years ago when digital media has not been so developed as it is now.

It is valuable to note that this research finding that the integration of Instagram and literature could portray a certain zeitgeist is only applicable to Instagram. Further, the zeitgeist that is happening is limited only in Indonesia. It is indisputable that further research on cyber literature with other digital media, e.g. Facebook, LINE, Twitter, Wattpad, Wordpress, etc., and the connection it has on a zeitgeist should be done more by scholars willing to study more about the impact cyber literature has on us.

Not only that, there have been arguments circulating about how the reading of cyber literature and our dependency on the Inter- net affected the way we think and treat reading materials. Two reports done by the National Endowment of Arts (NEA) in 2004 and 2007 suggested that there had been a significant decline in young people to read printed forms of literature, e.g. books, poetry, play (Katherine Hayles, 2012). This fact necessarily contributes to why young generations are prone to distraction and unable to get the gist of reading material (Katherine Hayles, 2012). Hayles' findings were supported by Carr's research on how reading digital material rewires and impairs our working memory (Carr, 2011). Responding to Carr's, Hayles contrastively believes that there is a beneficial aspect of reading digitally. Her conviction is that people who already read well in printed forms will be able to enhance their reading ability more in terms of reading digitally. Additionally, such debates about how we should treat online reading materials that fall under cyber literature and how it shapes the way we treat texts today led the authors of this research to believe that research and indepth study on cyber literature, zeitgeist, and its impacts are urgently needed to understand the nature of ever-changing cyber texts. Hopefully, this research would contribute a bit of spark to make the dialectical discussion about cyber literature more alive.

\section{References}

Anderson, P. 2019, August 19. Industry Notes: Wattpad Jumps to 80 Million Users, Cengage Sued Again. Retrieved November 4, 2019, from Publishing Perspectives website: https://publishingperspectives.com/ 2019/08/industry-notes-wattpad-jumps-to80-million-users-cengage-sued-again/ 
Poetika: Jurnal Ilmu Sastra

Vol. VII No. 2, Desember 2019

Barron, B. 2019, October 29. 2018's Most Surprising WordPress Statistics. Retrieved November 4, 2019, from Who Is Hosting This? website: https://www.whoishosting -this.com/compare/wordpress/stats/

Carr, N. 2011. The Shallows: What the Internet Is Doing to Our Brains. W. W. Norton \& Company.

Clement, J. 2019, August 9. Instagram: age distribution of global audiences 2019. Retrieved November 4, 2019, from Statista website: https://www.statista.com/ statistics/325587/instagram-global-agegroup/

Conder, X. F., \& López, A. 2012. Cyberliterature, Micro-stories, and Their Exploitation. Creativity and Cultural Awareness in Foreign Language Teaching, 4.

Desfourina, F. 2018, October 31. 6 Fakta di Balik Larisnya Nanti Kita Cerita Tentang Hari Ini. Retrieved November 5, 2019, from Review Buku Gramedia website: https://www.gramedia.com/blog/faktadi-balik-larisnya-buku-nanti-kita-ceritatentang-hari-ini-marchella-fp/

Eskelinen, M. 2012. Cybertext Poetics: International Texts in Critical Media Aesthetics. New York: Continuum.

FP, Marchella. 2019. Nanti Kita Cerita tentang Hari Ini. Jakarta: Gramedia Pustaka Utama.

IDN Times, \& Pertiwi, R. 2019, January 22. 10 Pesan Paling Berkesan dari Akun IG "NKCTHI", Menohok Nih! Retrieved November 5, 2019, from IDN Times website: https://www.idntimes.com/life/ inspiration/riana-pertiwi/10-pesan-nanti -kita-cerita-tentang-hari-ini-sudahtersampaikan-c1c2-1

Instagram. (n.d.). About Us. Retrieved November 3, 2019, from Instagram website: https://www.instagram.com/about/us/

Hayles, Katherine. 2012. How We Think: Digital Media and Contemporary Technogenesis. Chicago: University of Chicago Press.

Hooverm, D. L., Culpeper, J., \& O'Halloran, K.
DOI 10.22146/poetika.51207

ISSN 2338-5383 (print); 2503-4642 (online)

2014. Digital Literary Studies: Corpus Approaches to Poetry, Prose, and Drama. Routledge

Krause, M. 2019. What is Zeitgeist? Examining period-specific cultural patterns. Poetics. https://doi.org/10.1016/ j.poetic.2019.02.003

Kurniawan, E. 2019. Senyap yang Lebih Nyaring by Eka Kurniawan (T. Setiadi, Ed.). Yogyakarta: Circa.

Mooney, J. A. 2013, October 25. Internet Cookies, Personally Identifiable Information, and the Internet. Retrieved November 5, 2019, from The Coverage Inkwell website: https://www.whiteandwilliams.com/ media/alert/249_Coverage\%20Inkwell\% 2010.25.13.pdf

Nelson, T. 1993. Literary Machine. Sausalitu, CA: Mindful press.

Pignagnoli, V. 2019. Changing dominants, changing features? The fiction/nonfiction distinction in contemporary literary and Instagram narratives. European Journal of English Studies, 23(6), 224-238.

Rahman, F. 2017. Cyber Literature: A Reader Writer Interactivity. International Journal of Social Sciences \& Educational Studies, Vol. 7, pp. 156-164. https://doi.org/10.23918/ ijsses.v3i4p156

Rinaldi, M. R. 2019, April 27. Sastra Siber, Harapan realistis atau Angan-angan Belaka. Retrieved November 4, 2019, from Indonesiana website: https://www.indonesiana.id/ read/97102/sastra-siber-harapan-realistisatau-angan-angan-belaka

Ryan, M. L. 2013. Fictional Worlds in the Digital Age. In Siemens, R. \& Schreibman, S. (Eds). A Companion to Digital Literary Studies. Blackwell Publishing Ltd.

Sanz, A., \& Romero, D. 2007. Literatures in the Digital Era: Theory and Praxis. Newcastle: Cambridge Scholars Publishing.

Stout, D. 2019, July 8. Social Media Statistics: Top Social Networks by Popularity. Retrieved November 4, 2019, from Dustin Stout website: https://dustinstout.com/ 
Poetika: Jurnal Ilmu Sastra

Vol. VII No. 2, Desember 2019

social-media-statistics/

Webster, M. (n.d.). Definition of Zeitgeist. Retrieved November 3, 2019, from Merriam Webster website: https://www.merriam-
DOI 10.22146/poetika.51207 ISSN 2338-5383 (print); 2503-4642 (online)

webster.com/dictionary/zeitgeist Yongqing, Z. 2011. Reflecting on Online Literature. Social Sciences in China, 32(1), 182190. 